\title{
Management of home care by family caregivers to elderly after hospital discharge
}

\author{
Gestão do cuidado domiciliar por cuidadores familiares de idosos após a alta hospitalar
}

Gestión del cuidado domiciliario por parte de cuidadores familiares de ancianos luego del alta hospitalaria

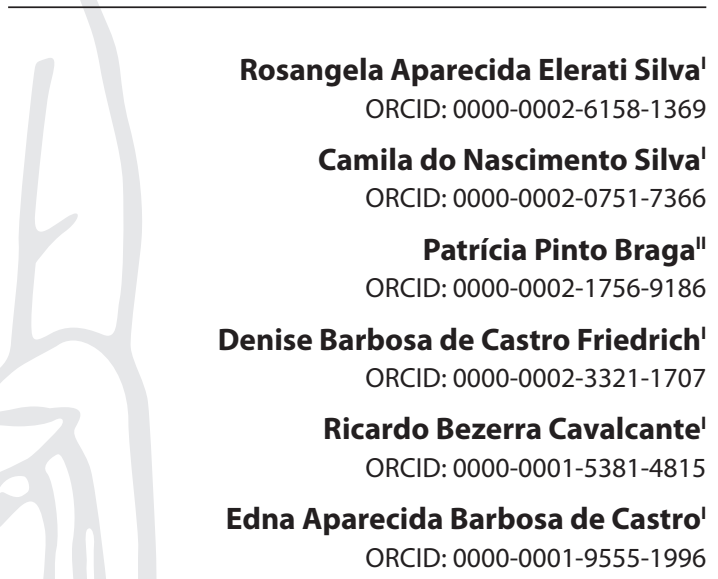

'Universidade Federal de Juiz de Fora. Juiz de Fora, Minas Gerais, Brazil.

"Universidade Federal de São João del Rei. São João del Rei, Minas Gerais, Brazil.

How to cite this article: Silva RAE, Silva CN, Braga PP, Friedrich DBC, Cavalcante RB Castro EAB. Management of home care by family caregivers to elderly after hospital discharge. Rev Bras Enferm. 2020;73(Suppl 3):e20200474. doi: http://dx.doi.org/10.1590/0034-7167-2020-0474

Corresponding author:

Edna Aparecida Barbosa de Castro E-mail: edna.castro@ufjf.edu.br

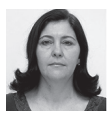

EDITOR IN CHIEF: Antonio José de Almeida Filho ASSOCIATE EDITOR: Ana Fátima Fernandes

Submission: $05-17-2020$

Approval: 09-14-2020

\section{ABSTRACT}

Objective: To understand the management of home care by family caregivers of dependent elderly people after hospital discharge. Methods: Qualitative research guided by hermeneuticsdialectic, anchored in the theory of communicative action. Data collection took place using a semi-structured interview with 11 participants. Results: Two categories were constructed: Management of the many types of care by the caregiver and the relationship between family caregiver and health care network. Care and management actions carried out routinely cause major changes in the family caregiver's life. He/she does not recognize planning, home care periodicity or support in required procedures. Final Considerations: The management of home care for dependent elderly people after hospital discharge is complex, involving physical and emotional overloads, as well as difficulties in getting support from health services. The planning shared between the health team and the family since the discharge is required, and the better visibility of the role of primary care when the patient is assisted by a home care service.

Descriptors: Aged; Caregivers; Nursing; Home Nursing; Primary Health Care.

\section{RESUMO}

Objetivo: Compreender a gestão do cuidado domiciliar por cuidadores familiares de idosos dependentes após a alta hospitalar. Métodos: Investigação qualitativa orientada pela hermenêutica-dialética, ancorada na teoria da ação comunicativa. Dados coletados por entrevista semiestruturada com 11 participantes. Resultados: Construíram-se duas categorias: Gerência da multiplicidade de cuidados pelo cuidador e Relação entre cuidador familiar e rede de atenção à saúde. Ações assistenciais e gerenciais realizadas rotineiramente provocam mudanças significativas na vida do cuidador familiar. Este não percebe planejamento, periodicidade de assistência domiciliar nem apoio em procedimentos requeridos. Considerações Finais: A gestão do cuidado domiciliar de idosos dependentes após a alta hospitalar é complexa, envolvendo sobrecargas física e emocional, bem como dificuldades em obter o apoio dos serviços de saúde. Requer o planejamento compartilhado entre equipe de saúde e família desde a alta e melhor visibilidade do papel da atenção primária quando o paciente é atendido por serviço de atenção domiciliar.

Descritores: Idoso; Cuidadores; Enfermagem; Assistência Domiciliar; Atenção Primária à Saúde.

\section{RESUMEN}

Objetivo: Comprender la gestión del cuidado domiciliario de cuidadores familiares de ancianos dependientes luego del alta hospitalaria. Métodos: Investigación cualitativa orientada por la hermenéutica-dialéctica, apoyada en teoría de la acción comunicativa. Datos recolectados mediante entrevista semiestructurada, con 11 participantes. Resultados: Elaboradas dos categorías: Gerenciamiento de múltiples cuidados del cuidador y Relación entre cuidador familiar y red de atención de salud. Las acciones asistenciales y de gestión rutinarias provocan cambios significativos en la vida del cuidador familiar, que no percibe planificación, periodicidad de atención domiciliaria ni apoyo para procedimientos necesarios. Consideraciones finales: La gestión del cuidado domiciliario de ancianos dependientes luego del alta hospitalaria es compleja, involucrando sobrecargas física, emocional y dificultad para obtener apoyo de los servicios de salud. Requiere planificación compartida entre equipo de salud y familia desde el alta, y mayor visibilidad del papel de la atención primaria cuando el paciente es atendido por servicios de atención domiciliaria.

Descriptores: Anciano; Cuidadores; Enfermería; Atención Domiciliaria de Salud; Atención Primaria de Salud. 


\section{INTRODUCTION}

The gradual increase in hospital admissions for the elderly due to acute causes or the worsening of chronic diseases is a phenomenon in the health scenario of contemporary societies, demanding the organization of services. Emphasis is given on health promotion in aging, through services with different technological densities, integrated and capable of embracing and resolving the care needs intrinsic in these people's lifeworld ${ }^{(1-2)}$.

In this perspective, the Atenção Domiciliar (AD) (Home Care), in the public policy form, joins the Rede de Atenção à Saúde (RAS), (Health Care Network) of the Sistema Único de Saúde (SUS), (Unified Health System), through the Serviços de Atenção Domiciliar (SADs) (Home Care Services), with potential to meet the demands of dependent elderly people, who still requires care needs after hospital discharge ${ }^{(3)}$. The elderly's hospital discharge expects the existence of integrated services, that can, with a gerontological view, embrace the elderly and their family, avoid readmissions, and promote the continuity of quality aging. The HC adds potential to include this view and respond to the dialogue between the RAS services, managing the transfer of care to the home context to assure the continuity of the service started in the hospital network ${ }^{(4)}$.

In the scope of this care, the Equipe Multiprofissional de Atenção Domiciliar (Emad) (Multi-professional Home Care Team) nurse seeks to integrate his actions both with hospitals, intermediating the discharge process, and with other RAS services, with emphasis on Atenção Primária à Saúde (APS) (Primary Health Care). In this sense, the nurse is the professional who dialogs/interacts with the nursing staff of the Estratégia de Saúde da Família (ESF) (Family Health Strategy), who, in the community, is co-participant in the care required by the patient and his family residing in his area of coverage $e^{(5)}$.

The transition between assistance models with the transfer of hospital care to the home, in de-hospitalization processes, reveals the need for a detailed analysis and investment in studies that clarify, in the management of home care for the elderly, the family and nursing roles in the offering of basic, instrumental and specialized care. The anticipated discharge for the continuity of care at home explains the complexity of the processes involved in the family and community scenario. Also, there is a growing demand for this type of care for elderly users.

Care management means providing and making health technologies available, according to the individual's unique needs, at different times in their life, aiming at their well-being, safety, and autonomy. According to this conception, care management involves five dimensions - individual, family, professional, organizational, systemic, and societal - dynamic and interdependent ${ }^{(6)}$. In this study, without intending to separate care management from its global context, emphasis will be given on the family dimension. In this research, aspects of family dynamics, their resources, ways of operating life are considered, not excluding contradictions, conflicts, pressures and burdens and their world of relationships, which includes health services, such as those of $\mathrm{HC}$, adding elements of the institutional logic of providing care ${ }^{(6)}$.

The focus on the family dimension is justified, since most of the elderly, after discharge, require care for the therapeutic approach to a disease or condition that manifests itself concomitantly with the natural conditions of the aging process, with the possibility of impairment or worsening of functional and cognitive capacity. The family needs to be prepared and supported by health professionals to face this situation ${ }^{(7)}$. Moreover, there is a shortage of caregivers in the face of the growing demand of this population, which highlights the need for training professionals to serve them and respond to the various issues involving the caregiver, considered a key element in the current SADs setting ${ }^{(8)}$.

The family caregiver joins the home care scenario for the dependent elderly person and often learns the elderly care actions alone, searching for a support network and resources for care, which includes access to information, equipment, and materials. Furthermore, they need to deal with pressures and conflicts in family relationships, as well as to reconcile the time to carry out their activities ${ }^{(9)}$. Thus, home care needs to be compatible with these needs, aiming not only at adapting the caregiver to the changes that take place in their lifestyle when assisting the elderly family member, but also at promoting, preserving and maintaining their health ${ }^{(10)}$.

To improve the understanding of the care management of elderly people dependent on home care, it is important to identify the types of support that the family needs, considering the dialogue with the existing health services in the RAS, especially with the ESF. Knowing what the demand is, when and how family members demand and organize this type of care is crucial, as it constitutes the basis for the development of instruments for planning health actions and systematizing the care process $s^{(3,10)}$. Thus, the investigation question that guided the objective of this study was: how does care management by family caregivers in the HC service to dependent elderly people occur after hospital discharge in SUS?

\section{OBJECTIVE}

To understand the management of home care by family caregivers of dependent elderly people after hospital discharge.

\section{METHODS}

\section{Ethical aspects}

The study followed the formal requirements in national and international guidelines for research involving human beings. The project was approved by the Research Ethics Committee of the proposing institution.

\section{Theoretical-methodological framework}

The research was carried out upon the Dialectic Hermeneutics methodological framework and procedures ${ }^{(11-12)}$, based on the theory of communicative action by Jürgen Habermas ${ }^{(13)}$. This option is justified by subject outline, focused in the context of relations between citizens and health services, in which praxis is extracted in its full sense, according to an ethical-political thought that does not disconnect it from the lifeworld and events, preceding the construction of science. The communicative action 
theory contributes to understanding and explaining the home care management phenomenon through interchanges, dialogues and communicative actions established between professionals and users, according to three specific components to the: culture, society, and the person.

\section{Type of study}

This is a qualitative, comprehensive-explanatory investigation, guided by the hermeneutic-dialectic method, anchored in the theory of communicative action by Jürgen Habermas, and reported according to the Consolidated Criteria for Reporting Qualitative Research (COREQ) protocol.

\section{Study setting}

The research took place in a medium-sized municipality in Minas Gerais, with 564,319 inhabitants, where a total of 74,049 elderly people (13.12\% of the general population) is estimated. The RAS services are allocated in eight health regions and have 63 UBSs, 42 with ESF and 21 in the usual model, three Emergency Care Units, 11 hospitals and a Home Care service with five Emads and a Multi-professional Support Team (Emap).

\section{Data source}

From April 2017 to March 2018, the municipality had 6,825 hospitalized elderly people who were discharged from the hospital, among which 5,486 (80.38\%) lived in areas covered by APS, with 3,751 (68.37\%) hospital discharge of elderly residents in areas covered by UBS with ESF. Of the total of 6,825 hospital discharges, 89 elderly people, after discharge, were admitted/followed up in the SAD. Among the elderly admitted to the SAD, 13 were selected to participate in the research, and the statements of their caregivers collected through semi-structured interviews were the data source.

\section{Study participants}

There was intentional inclusion of caregivers, over 18 years old, considered primary caregivers, responsible for an elderly family member, dependent on home care after hospital discharge, obtained from April 2017 to March 2018, and residents on streets belonging to one of the UBSs with ESF in the city where the research was carried out. Two caregivers who indirectly assisted partially dependent elderly people who lived alone were excluded.

\section{Methodological procedures}

The research was developed in two phases. In the first, secondary data were retrieved from the SUS Department of Informatic official banks, from the user registration worksheets by Emad from SAD/Programa Melhor em Casa (Better at Home Program) and from medical records. The objective was to explore and describe the research scenario to identify potential participants. In the second phase, Home Visits (VDs) took place to access participants and collect data. The VDs were carried out by the main researcher, in the process of training for an academic master's degree, accompanied by a nursing undergraduate student, both experienced on how the services work, but without previous relations with the participants.

The VD included three procedures: (1) obtaining sociodemographic and health data, using structured instruments, specifically designed to collect information about sex, age, marital status, education, religion, skin color, profession, income, illnesses of the elderly person and from the main family caregiver, degree of relationship with the family caregiver, time being a caregiver and number of hours dedicated to caring for the elderly family member; (2) confirmation of the elderly's level of dependence (specific research script, with questions about basic and instrumental activities of daily living, interaction and attention and communication cognitive skills); (3) interview guided by a semistructured script with the following triggering questions: what is it like for you to have to take care of an elderly relative dependent on home care after hospital discharge? How does UBS nursing participate in care at home after hospital discharge? How do you perceive the UBS nursing care, considering that your elderly family member is admitted to the $\mathrm{HC}$ service? The average time to obtain each statement was 50 minutes.

\section{Data collection and organization}

The interviews were conducted in a reserved space, restricted to researchers and the participant, to provide privacy and security. They were interrupted with the theoretical saturation of the data, that is, when the information was sufficient to answer the study questions ${ }^{(14)}$. There was no refusal or rejection from participating in the research.

Before each VD, telephone contact was made to the family caregivers of the elderly identified in the first phase, to schedule the most convenient day and time. The interviews were conducted only once and sequentially, after signing the Informed Consent Form. All statements were recorded using a smartphone device in offline mode and then transcribed in full, adjusting only wordiness, observing not to modify the essential characteristics of the text and its expressed meaning. To guarantee anonymity, caregivers received alphanumeric codes, starting with the letter C, followed by the interview number (Example: C01). The textual data were organized and edited with the support of the Open Logos Software in version $2.0^{(15)}$.

\section{Data analysis}

The analysis of the data collected in the first stage consisted of exploring the scenario for qualitative research, an aspect inherent to research guided by Dialectic Hermeneutics. The documented data resulting from the interviews were ordered, classified, contextualized and analyzed, according to the proposition of the theoretical framework, with the following steps: the ordering of the data after transcription of the recorded interviews, re-reading the material, organization in a textual database with the support of the Open Logos 2.0 software, establishing the corpus that was technically worked.

In the data classification phase, it was performed a horizontal and exhaustive reading of the texts. Then, a cross-sectional reading of each subgroup and the entire group was carried out ${ }^{(12)}$. 
After the analysis of the participants' speeches on issues in line with the theory of communicative action, two categories were constructed: Management of the many types of care by the caregiver and Relationship between family caregiver and health care network, presented below. The theoretical framework ${ }^{(13)}$ supports and allows interpretations and inferences about the issue and the discussion with results from other national and international research published on the theme.

\section{RESULTS}

Initially, the sociodemographic characteristics, health and care needs of the 11 elderly people who received home care were presented, as well as the characterization of the caregivers who participated in the research, to better understand the care and management actions in this context.

The average age of the elderly was 75 years, ten were Catholic, 11 were retired with up to two minimum wages, three were illiterate and eight had incomplete I and II elementary school. All lived with chronic non-communicable diseases, nine of whom had a chronic obstructive pulmonary disease and ten had systemic arterial hypertension. Moreover, other diseases such as Alzheimer's, diabetes mellitus, stroke, chronic renal failure, and joint diseases were observed among the elderly. All elderly people took five or more medications daily, demanding assistance or care to meet needs related to basic and instrumental activities of daily living and therapeutic procedures: dressings, medications, oxygen therapy, nutritional support and others related to mental health.

The 11 caregivers interviewed lived with the elderly family member, seven were over 60 years of age, five had incomplete I or II primary education, ten were female, seven being wife and primary caregiver, and five had been caring for more than five years for the elderly relative.

\section{Management of the many types of care by the caregiver}

When assisting in the family context, the caregiver mentions the difficulties related to the daily routine activities, explaining the adjustments made in the family organization:

The first thing was to move out... Because of his tiredness, the house had steps. So ... That was the first thing. (C04)

After he got sick, then everyone's routine changed, because everyone had to help in the way they could. Whoever had a job left it to be able to take care ... [...] at home, the routine changed a lot, because even our food we had to change (C11)

There is no way to go out and leave him [...]. We don't go out ... We don't have leisure, we don't... Because sometimes we could go out, but he is discouraged, feeling pain in his legs. (C06)

The main caregiver points to the performance of multiple activities to meet the needs of the elderly, including care with hygiene, food, medications, dressings, and therapeutic procedures, such as oxygen therapy. He mentions a daily routine that requires his constant presence for the family member, 24 hours a day, when making decisions, prioritizing safety:
We take it over 24 hours a day. [...] Every care! [...] medication, food, bath ... (C01)

[...] we bathe, give medicine ... everything she needs, we don't consider difficulty ... It's so much that you do [...] just like the times she had diarrhea. So, I had to change her two, three times in the morning. Sometimes, medicine too, it didn't suit well, then it caused a problem. (CO3)

The oxygen, the medications, dressing on the foot, because he has a wound on his foot, but it is already healed, but you have to keep looking to see if it doesn't come back, yeah ... looking for gauze at the health unit. (C11)

So, she came here yesterday [nurse], I told her that now I'm giving him a bed bath because, if something happens... It's food, bath, medication [...] I stay most of the time inside the room, not to leave him alone. (C02)

In the daily routine, the participants report carrying other household tasks, such as washing clothes, preparing food, taking care of grandchildren, besides assisting the elderly relative in their needs, sometimes counting on the support of other family members:

[...] what I do daily is my obligation, cooking, laundry, I take care of my granddaughter, I clean the house [...]. We do what we can [...]. (CO9)

[...] / don't let his sheets get dirty with pee [urine]. I do not! If it gets wet, [the clothes] goes to the washing machine. [...] His clothes are always clean, here in the drawer (C08)

If I have to go out, then my sister takes him for hemodialysis, she bathes, she cleans up. (C07)

[...] to take him to the bathroom and come back with him, shower, usually my son helps [...]. But the time to dry his legs, which he cannot lower because he gets tired, I do it. Except for the day he is doing well, then he does everything himself. (C10)

\section{The relationship between family caregiver and health care network}

In their speeches, caregivers point out that the UBS contributes to the care they perform at home, and that they seek support in the service regarding supplies and guidance for therapeutic care related to the treatment of the disease of the elderly under their care:

When I go there [UBS], I am very well supported in everything I request. [...] I go there more because of the prescriptions. She wears a diaper and, to get a diaper at the Health Department, she needs the prescription. Then, I go to the health unit. (C05)

[...] the health agent who comes by from time to time. [...] She lives near here. So, she usually stops by. Then, I talk, sometimes I ask for something, some guidance, some help... (C08)

When he came home, they [health professionals] came, offered to do the dressing [...] they came to do the dressing, taught her how to do it [...] they gave a lot of attention, they give a lot of attention to people. (C02) 
According to the participants, despite the territorial approach, home care is only provided when requested by the family caregiver, without planning and periodicity:

Oh, it would be good if they made a consultation at home, a visit. If from time to time, someone would come of their own free will, or call to ask how it is, since we live so close [...], but we need to ask for it. (C07)

There are no visits for him. Seldomly, someone from the health unit shows up there. But you have to ask, you know? (C09)

As he is not able to walk alone, they should visit from time to time. The doctor goes around the houses and she doesn't come to mine. She came this year, I can say she came once in January. (C11)

Regarding nursing, the participants expect it to contribute to the management of care through attention, guidance, besides teaching and support for carrying out procedures. However, they criticize the absence of nurses in home visits:

I think that ... is to come by, ask if you need anything, that palliative. [...] the nurse's presence, come here, see what is missing and what is not missing. ( $\mathrm{CO} 3)$

[...] from the health unit around here I have nothing to complain about, sometimes the absence of nurses, who should watch closely his case. I know some people have a worse problem than him. (C11)

[...] we just needed their support to come here [home], check his blood pressure, find out how he is at least. Once a month, it would help, check his glucose, see if there is a need to increase the dose, because we are giving 20 units. Now we don't know whether it is working or not. (C08)

According to the participants, the lack of material resources and medicines at the UBS makes it difficult to manage home care. To meet the care demands of the dependent elderly family member after discharge, caregivers seek other RAS points:

I almost don't go to the health unit, because, when we get there, they [...] don't have resources, they don't have a computer, everything is recorded, paper, it's like in my grandfather's time [...] will to attend it is not enough. (C10)

Oh, they can't do much ... medicine is missing. The other day, I needed to get an ointment, she [doctor] did not prescribe. (C03)

We ask for assistance there at the health unit only when he is in great need because he is already very well assisted at the hospital. There are all doctors, exams, everything is done there. (C11)

Every time he gets sick, we go straight to the UPA. At the clinic, it's more about control and getting the medicine. (C01)

\section{DISCUSSION}

This study shows that the management of home care by family caregivers of an elderly person after hospital discharge takes place in a complex context of care, involving physical and emotional overloads related to care routines, to compensate for the deficiencies of the elderly family member in maintaining basic daily activities, and management, to meet the demands of treatment, prevention of grievances and readmission. It also involves difficulties in obtaining support from health services for home care. This is corroborated by findings from an Australian study that shows, besides these aspects, that patients and caregivers have progressively taken over the burden of treatment when the elderly goes from the hospital to the home setting ${ }^{(16)}$.

The caregiver routine aims to meet the demands related to the basic activities of the daily life of the hospitalized elderly, which causes the need for adaptation in the family organization. The feeling of being responsible for everything was shown to be a major characteristic of the caregivers' experience in this area and exposed their need to have time for themselves. These caregivers seek support from other family members as the elderly person becomes more dependent and/or the demand for care increases. However, in line with other studies, the participants explained that the tasks associated with caring are assigned to the primary caregiver, causing an imbalance in the family unit due to the diversity and quantity of activities to be performed ${ }^{(9-10)}$.

The statements show that, besides assuming the role of primary caregiver, they preserve the hygiene of the home environment and the elderly's personal, bed and bath clothing, make choices and adaptations with the new demands that arise in daily care, develop skills to identify the rise of new situations, which require more dedication, in addition to caring for grandchildren. Especially when home care is carried out by a single family member, the role of the caregiver becomes more stressful, compromising his/her health, which causes isolation and impairs sociability ${ }^{(17)}$. Caring should be understood as a role that can be shared with other family members, such as siblings, sons-in-law, husbands and even with the health service. However, it is possible to recognize that, in practice, there is not always sharing of tasks, which causes overload to the main family caregiver ${ }^{(18)}$.

Participants report having the help of other family members in some situations, such as assisting in the elderly's hygiene and in taking them to health services. Even when the hospitalized elderly person is not completely dependent, the caregiver remains present, assisting him/her in basic activities, such as dressing clothes, putting on socks, eating, added to the very vital needs, of a therapeutic nature, such as oxygen therapy, medication administration, dressing. However, the multiple care and managerial care, sometimes of high complexity, are developed simultaneously by the caregiver, over 24 hours, and they do not always have a social network, support or supervision from health service to teach and monitor. This impairs care for the elderly and causes emotional distress for the caregiver ${ }^{(10,19)}$.

After hospital discharge, the family caregiver is a key element to help the elderly in adapting to daily life. However, this activity is a challenge, as the elderly and their families create conditions that can result in unsafe practices in the management of care at home. Some factors can contribute to this, such as, unpreparedness to take on the new health situation, problems in the home environment, lack of specialized equipment and supplies, the inability of the elderly to perform physical activities and propensity to isolation ${ }^{(20)}$. Moreover, it is necessary to consider that guidelines for self-care and care management at home, provided at discharge, may or may not be followed by the patient and family, which requires the involvement of health services in the home care management ${ }^{(20)}$. 
The constant dialogue between the family caregiver of the dependent elderly person after hospital discharge and RAS services, including home support by APS professionals, can assist caregivers in providing care. With communicative actions, a common point can be reached, exposing the need to rebuild a space for ethical discussion among family caregivers for the elderly, who must remain open and critical. It is presumed in this analysis that the rationality implicit in the management of home care for dependent elderly people is inspired by social relationships, through intersubjectivity, which allows autonomy in the care process and with a greater understanding of the being and being in the health care world ${ }^{(13)}$.

Caregivers report being embraced by the UBS multi-professional team, however, in their speeches, they point to obstacles to comprehensive care, such as the lack of technological innovation and the absence of appropriate material resources for care. Moreover, they emphasize that the support offered is given only at the health unit itself and not at the user's home, that is, the service is limited to the availability of materials that the caregiver will pick up, such as prescriptions and medications, sometimes unavailable. Considering the need for assistance mentioned by the caregiver, it is emphasized that formal support is necessary, with emphasis on the role of nursing care as a chance of support ${ }^{(7)}$. Given the daily demands of patient care, Nursing must seek strategies to reduce the suffering of family members, both at discharge and in home care ${ }^{(21)}$.

The assistance offered by the UBS, according to the statements of the caregivers, does not meet the expectation they had when taking over home care for the elderly family member after discharge. The constant search for the service makes home care even more difficult, requiring more work and effort on the part of the family. These issues become noticeable when respondents report that they seek UBS to request VDs from professionals and that these do not happen. The VD is an important care strategy to produce creative and unique care constructions, strengthening the care practices for the elderly ${ }^{(22)}$.

There is a gap in the UBSs' services in the context researched, given that the VD, besides being a strategy for the care of elderly dependents by the ESF, stimulates dialogue with the SADs to prevent hospital readmissions in the short and long term after discharge. Attention by home care services prevents mortality and contributes to increasing the quality of life, functional level, and cognitive skills of patients, which can be more cost-effective than hospital service ${ }^{(23)}$. However, a single visit by a specialized team is not enough to prevent readmissions.

It is emphasized that, in the family context, both ESF and SAD professionals can assist caregivers in care and management actions for the dependent elderly. Families need professional support so that they can organize and establish a care routine and adequately perform their role in care ${ }^{(10)}$.

The ESF can be considered as a strategy to support the management of home care for dependent elderly, in which the team responsible for the VD will accompany the patient with organized practices, technological instruments, knowledge and powers ${ }^{(24)}$. Professional supervision and the agreement of objectives, goals, and duties among those involved in caring for the elderly will help family members to assume their role as providers of care, with the support of the health system ${ }^{(25)}$.
Based on the above, it is confirmed the importance of family caregivers to become the target of specific public policy, since the responsibility for the care of elderly and sick people demands the dialogue between the family and the State, considering that the home caregiver is active in care management, with the power to interfere in the health professionals' care plan.

It was found that the caregivers of elderly people hospitalized with complex chronic conditions with the potential for aggravation sought assistance for care beyond the UBS, in the outpatient emergency services for support or in outpatient clinics linked to a hospital in acute events. This result points to the need to establish spaces for interinstitutional articulation in which the agreement on service flows is a priority, especially with APS services. It is noteworthy that the APS services are recognized by the National Home Care Policy as a privileged range of care, being responsible for most of the care in $\mathrm{HC}$ in $\mathrm{Brazi}^{(26)}$. With a view to comprehensive care for the elderly, $\mathrm{HC}$ needs to be supported by the RAS, with dynamic articulation at different levels of care and services ${ }^{(21)}$.

Thinking home care management from the health professionals' perspective, which comprises Nursing, one must consider the fact that the person requiring care is elderly and home care is a process inherent to the ESF work. It is emphasized that the participants' perception of the ESF nursing team is positive, although they highlight the lack of nurses in systematic care at the patient's home in to provide care, education and support to family members in carrying out procedures. To define the type of care that the elderly needs at home, skills related to geriatrics and gerontology areas is essential for nurses to approach the health promotion of the elderly, providing comprehensive care, without prioritizing only the elderly who have diseases or grievances ${ }^{(27)}$.

Because of the great demand for teamwork, one of the criteria that has been used by nurses in the systematization of VDs is the family risk assessment. However, despite being an important care option for dependent elderly people, this practice needs to be shared with other support networks that can continue to care for the elderly and their caregivers ${ }^{(28)}$.

According to Habermas ${ }^{(13)}$, home care management can be understood through dialogue, in a given context ran by social norms, between the family, registered in the lifeworld, subjective, full of experiences and feelings, and the health services, inserted in an objective and coherent system, through its modes of organization and logics of professional work. The communication established between these subjects about the necessary and actions held for the care of the elderly at home points out their demands and explicit them.

The family of the dependent hospitalized elderly needs professional support to get prepared to welcome and manage the care of this elderly person, evaluate, and provide resources that meet the needs of home care. Health professionals, as for their expertise about care, need to seek competences in addition to those they bring from their education, to understand the complex needs of the home care context, considering the aging process and the available apparatus technological resources.

\section{Limitations of the study}

In this study, the approach to the issue was made from the perspective of family caregivers of dependent elderly people. Other 
dimensions make up the management of home care and require specific investigations. The data found describe a reality that can be different from another, which does not allow the generalization of the results.

\section{Contributions to the area of nursing, Health and Public Policy}

The findings of this research contribute to the work of nurses in health care for the dependent elderly, as they provide subsidies for decision making in the field of systematization of nursing care, through integrated care plans between professionals from the SAD and ESF who praise the participation of the family caregiver both as an agent and as a subject in the care process. The study contributes to reflections on the relevance of health promotion for elderly people dependent on family care after hospital discharge to prevent readmissions and the quality of the aging process. It reinforces the importance of implementing public policies that direct actions to family caregivers towards the qualification of health care for the elderly from existing strategies.

\section{FINAL CONSIDERATIONS}

This investigation enabled the understanding of care management in home care for the elderly after hospital discharge from the perspective of family caregivers is established through care and management actions carried out routinely, causing significant changes in the family caregiver's life. Added to this is the fact that this caregiver does not understand planning, periodicity of home care, or continuous support in procedures required by the elderly under their care.

The care management for dependent elderly people after discharge at home is complex, involving physical and emotional overload, besides the difficulties in obtaining support from health services. It requires planning shared between the health team and the family from the moment of the discharge and better visibility of the role of APS when the patient is assisted by a home care service. The importance of keeping the link between the elderly and APS services is emphasized when they are enrolled with SAD, given the importance of supporting this level of care in actions to promote and recover health and prevent health problems and readmissions.

It is suggested to carry out further investigations in the home care scope concerning the elderly population, considering that $\mathrm{HC}$ has the potential to reduce hospitalization and readmissions, contributing to improving the quality of life of the elderly and family caregivers.

\section{FUNDING}

We would like to thank the Federal University of Juiz de Fora, Brazil, for the financial support for this research.

\section{REFERENCES}

1. Castro EAB, Leone DRR, Santos CM, Gonçalves Neta FCC, Gonçalves JRL, Contim D, et al. Home care organization with the Better at Home Program. Rev Gaúcha Enferm. 2018;39:e2016-0002. doi: 10.1590/1983-1447.2018.2016-0002

2. Silva KL, Castro EAB, Toledo ST, Gonçalves J, Ribeiro AD. Political pathway of home health care in Minas Gerais. Rev Min Enferm. 2019;23:e1155. doi: 10.5935/1415-2762.20190002

3. Chibante CL, Santos TD, Valente GC, Espírito Santo, FH, Santos L. Nursing care management to elderly patients: the search for evidence. Rev Enferm UFPE. 2016;10(Supl.2):848-58. doi: 10.5205/reuol.6884-59404-2-SM-1.1002sup201620

4. Xavier GTO, Nascimento VB, Carneiro JN. The contribution of home care to the construction of health care networks from the perspective of health professionals and elderly users. Rev Bras Geriatr Gerontol. 2019;22(2):e180151. doi: 10.1590/1981-22562019022.180151

5. Andrade AM, Silva KL, Seixas CT, Braga PP. Nursing practice in home care: an integrative literature review. Rev Bras Enferm. 2017;70(1):199208. doi: 10.1590/0034-7167-2016-0214

6. Cecílio LCO. Apontamentos teórico-conceituais sobre processos avaliativos considerando as múltiplas dimensões da gestão do cuidado em saúde. Interface (Botucatu). 2011;15(37):589-599. doi: 10.1590/S1414-32832011000200021

7. Costa SRD, Castro EAB, Acioli S. Nursing support for self-care of family caregivers. Rev Enferm UERJ. 2015;23(2):197-202. doi: 10.12957/ reuerj.2015.16494

8. Braga PP, Sena RR, Seixas CT, Castro EAB, Andrade AM, Silva YC. Oferta e demanda na atenção domiciliar em saúde. Ciên Saúde Colet. 2016;21(3):903-12. doi: 10.1590/1413-81232015213.11382015

9. Fernandes CS, Angelo M. Family caregivers: what do they need? An integrative review. Rev Esc Enferm USP. 2016;50(4):675-82. doi: 10.1590/ S0080-623420160000500019

10. Couto AM, Caldas CP, Castro EAB. Family caregiver of older adults and Cultural Care in Nursing care. Rev Bras Enferm. 2018;71(3):959-66. doi: 10.1590/0034-7167-2017-0105

11. Stein E. Dialética e hermenêutica. Síntese [Internet]. 2003 [cited 2020 Jun 11];10(29):21-48. Available from: https://faje.edu.br/periodicos/ index.php/Sintese/article/view/2087/2381

12. Minayo MCS. O desafio do conhecimento: pesquisa qualitativa em saúde. 14.ed. São Paulo: Hucitec; 2014.416 p.

13. Habermas J. Teoria do agir comunicativo: racionalidade da ação e racionalização social. São Paulo: Martins Fontes; 2012.736 p.

14. Nelson J. Using conceptual depth criteria: addressing the challenge of reaching saturation in qualitative research. QRJ. 2016;17(5):554-70. doi: $10.1177 / 1468794116679873$ 
15. Camargo Jr KR. Apresentando Logos: um gerenciador de dados textuais. Cad Saúde Pública. 2000;16(1):278-87. doi: 10.1590/ S0102-311X2000000100032

16. Slatyer S, Aoun SM, Hill KD, Walsh D, Whitty D, Toye C. Caregivers' experiences of a home support program after the hospital discharge of an older family member: a qualitative analysis. BMC Health Serv Res. 2019;19:220. doi.org/10.1186/s12913-019-4042-0

17. Mocelin C, Silva TG, Celich K, Madureira VF, Souza SS, Colliselli L. The care of dependent elderly on the family context. Rev Pesqui. 2017;9(4):1034-39. doi: 10.9789/2175-5361.2017.v9i4.1034-1039

18. Yavo IS, Campos EMP. Cuidador e cuidado: o sujeito e suas relações no contexto da assistência domiciliar. Psicol Teor Prát. 2016;18(1):20-32. doi: 10.15348/1980-6906/psicologia.v18n1p20-32

19. Santos Sousa Jl, Silva BT, Rosa BM, Garcia EDQM, Roque TS. Sobrecarga de trabalho em familiares de idosos em cuidados paliativos. Res, Soc Dev. 2020;9(4): e146943001. doi:10.33448/rsd-v9i4.3001

20. Hestevik CH, Molin M, Debesay J, Bergland A, Bye A. Older persons' experiences of adapting to daily life at home after hospital discharge: a qualitative meta summary. BMC Health Serv Res. 2019;19(1):224. doi: 10.1186 / s12913-019-4035-z

21. Procópio LCR, Seixas CT, Avellar RS, Silva KL, Santos MLM. Home Care within the Unified Health System: challenges and potentialities. Saúde Debate. 2019;43(121):592-604. doi: 10.1590/0103-1104201912123

22. Assis AS, Castro-Silva CR. Agente comunitário de saúde e o idoso: visita domiciliar e práticas de cuidado. Physis. 2018;28(3):e280308. doi: $10.1590 / s 0103-73312018280308$

23. Lembeck MA, Thygesen LC, Sørensen BD, Rasmussen LL, Holm EA. Effect of single follow-up home visit on readmission in a group of frail elderly patients: a Danish randomized clinical trial. BMC Health Serv Res. 2019;19:751. doi: 10.1186/s12913-019-4528-9

24. Oliveira SG, Kruse MHL. Better off at home: safety device. Texto \& contexto enferm. 2017;26(1):e2660015. doi: 10.1590/0104-07072017002660015.

25. Muniz EA, Freitas CASL, Oliveira EN, Lacerda MR. Grau de sobrecarga dos cuidadores de idosos atendidos em domicílio pela Estratégia Saúde da Família. Saúde Debate. 2016;40(110):172-82. doi: 10.1590/0103-1104201611013

26. Savassi LCM. Os atuais desafios da Atenção Domiciliar na Atenção Primária à Saúde: uma análise na perspectiva do Sistema Único de Saúde. Rev Bras Med Fam Comunidade. 2016;11(38):1-12. doi: 10.5712/rbmfc11(38)1259

27. Anjos KF, Boery RNSO, Bacelar K, Santa Rosa DO. Responsibilities for the care with the dependent elderly in the household. Rev Baiana Enferm. 2020;34:e34893. doi: 10.18471/rbe.v34.34893

28. Nakata PT, Costa FM, Bruzamol CD. Nursing care for the elderly in the family health strategy. Rev Enferm UFPE. 2017; 11(Supl.1):393-402. doi: 10.5205/reuol.7995-69931-4-SM.1101 sup201719 